\title{
Rural Society's Interpretation of Modern Architecture Represented by Television
}

\author{
Nisa Kurnia Illahiati ${ }^{1}$ \\ ${ }^{1}$ Communication Department, Airlangga University
}

\begin{abstract}
This paper focused on how rural societies interpret the concept of modern architecture represented by television and presenting it in the form of their houses and how they used their space. My starting point came from humanity perspectives where individual as part of larger society that used the same language will interpret symbolic usage in text as their own culture. So, this paper will show the appearances and shapes of rural society's livable space created from their interpretation of modern architecture represented by television. I'm conducting a research to answer those challenges using visual methodology and in-depth interview in two villages located in East Java Province. The result of my research reinforce my basic assumption that the people in rural society's used television as modernization agent including give them manual to used their space in modern way. However, the rural society combined what they considered as modern value and their own local value into creating space that accommodate their needs.
\end{abstract}

Keywords: modern architecture, rural society, television, representation, interpretation.

\section{Introduction}

Creating space for better life is one's decision to make. In this paper, I will describe how rural society interpreted the concept or modern architecture represented by television, then adopt into their daily live space. Starting from humanity paradigm, where individual is part of the larger society so they will interpret any symbol as told by their own culture, this paper will shows how local wisdom and socio cultural condition affect rural society's interpretation of modern architecture. Furthermore, this paper will shows the appearance and shape of rural society's livable space created from their interpretation of modern architecture represented by television. Considering that rural society's doesn't really know about the academic concept of modern architecture, but they can create their version of 'modern architecture' referenced from the television.

Television as the dominated information channel of rural society, becoming one of others media that connect them to a larger society. They expect that everything shown in television is the genuine practices that translate the concept of modernity. So they blindly adopt it into their daily lives. However, television programs as part of mass media will never shown reality as it is. Every reality that shown in television were screening through producer's eyes into something better and depends on their definition on reality, we called this representation. To sum up, this representation gives rural viewer perception about their definition of modern architecture and the rural society adopt its concept.

But, without any knowledge on the modern architecture itself, rural society thinks that modern architecture represented by media is the right one. However, to adopt the pseudo-reality on modern architecture is not easy as it seems, because of the local wisdom and socio-cultural landscape of rural area, they will modify the representation into something new. So, this paper attempt to describe how they interpreted the concept of modern architecture created by the television into something by comparing their home appearance/shape with those on television.

In this paper I will present my research as media studies scholar who looking at architectural phenomenon in the rural area. My stand point in this paper is that people used media, television in this context, to guide their lives. This general assumption also applies in terms of architectural form represented in television as the audience guide of what consider ideal in society. In conclusion, I assume that people in rural area used architectural image in television as their standards of modern and livable space. 


\section{Methodology}

Methodology used in this research is combination between visual observation and in-depth interview to the villagers as part of the rural society. This research conducted in September until October 2011 in two rural areas. First is the Ngadi Luwih village located in Kediri and the second is Turen village located in Malang, both in East java province. The result from the visual observation will be photograph of the village condition and the result from in-depth interview will be narrative of people interpretation about modern architecture. In the result and discussion part of this paper I will combine the photographic data and the qualitative narration and discuss it with theory.

\section{Result and Discussion}

\subsection{Basic Assumption about Modern Architecture}

"Form Follows Functions" believed as central value of modern architecture. Modern architecture is generally characterized by simplification of form and creation of ornament from the structure and theme of the building. It is a term applied to an overarching movement, with its exact definition and scope varying widely. In a broader sense, modern architecture began at the turn of the 20th century with efforts to reconcile the principles underlying architectural design with rapid technological advancement and the modernization of society. It would take the form of numerous movements, schools of design, and architectural styles, some in tension with one another, and often equally defying such classification.

The concept of modernism would be a central theme in these efforts. Gaining popularity after the Second World War, architectural modernism was adopted by many influential architects and architectural educators, and continues as a dominant architectural style for institutional and corporate buildings into the 21 st century. Modernism eventually generated reactions, most notably Postmodernism which sought to preserve pre-modern elements.

Common themes of modern architecture include: the notion that "Form follows function", a dictum originally expressed by Frank Lloyd Wright's early mentor Louis Sullivan, meaning that the result of design should derive directly from its purpose. Furthermore, simplicity and clarity of forms and elimination of "unnecessary detail" is absolute. Visual expression of structure (as opposed to the hiding of structural elements) and the related concept of "Truth to materials", meaning that the true nature or natural appearance of a material ought to be seen rather than concealed or altered to represent something else. The use of industrially-produced materials; adoption of the machine aesthetic becoming one of signature point in the form of modern architecture. Particularly in International Style modernism, there is a visual emphasis on horizontal and vertical lines.

Further, this modern architecture signature also shown in one of the most common object we meet in our daily lives, the house. Cacciari ${ }^{1}$ considered modern houses as the primary intimacy of the architecture itself:

The house constituted a "primary intimacy": all "consideration of objects", all contemplation proceeds from the house, has the house as its premise. No theory is absolute, independent of the house. The idealism that asserts the ego as perfectly displaced corresponds to the idealism of Architect who would like to built the house ex novo, who understands the house as a free product of his transcendental purpose.

By looking at the architecture, the house communicates how people live inside it. The use of livable spaces becomes linier with the central philosophy of modernity itself. The differentiation of private and public spaces becoming one of the most urgent point to be articulated in the form of house itself.

Nowadays the ecological discourse also considered as part of modern houses architecture. Like Downton ${ }^{2}$ said:

In many ways a house can sum up a region. It can tell about the land - its weather, its materials, its topography, even its safety from invasion. But a house is not predetermined by these elements. A house, however simple, also tells about its inhabitants - where they have come from, what they believe, how they live. At its best, a house is a fusion of commonsense and poetry. Because of its

\footnotetext{
${ }^{1}$ Cacciari, Massimo. (1993). Architecture and Nihilism: On The Philosophy Of Modern Architecture. London: Yale University Press. pp. 143-195

${ }^{2}$ Downton, Paul F. (2009). Ecopolis: Architecture And Cities For A Changing Climate. Australia: Springer Science Publishing. pp. 179-220
} 
natural and primal role, the house often leaves a mark on subsequent generations of buildings and, in so doing, creates a legacy - a regional identity, perhaps - that can be very powerful indeed. Through the house we sometimes manage to create a precious cultural gift - a genuine sense of place.

More simplistic and shown an ecological point of view is the central idea of the livable spaces articulating in the form of houses. Moreover the characteristics of houses physical appearances also shown the cultural originality of society live in it. This basic assumption becoming my starting point in my research about rural societies interpret the concept of modern architecture represented by television and presenting it in the form of their houses and how they used their space.

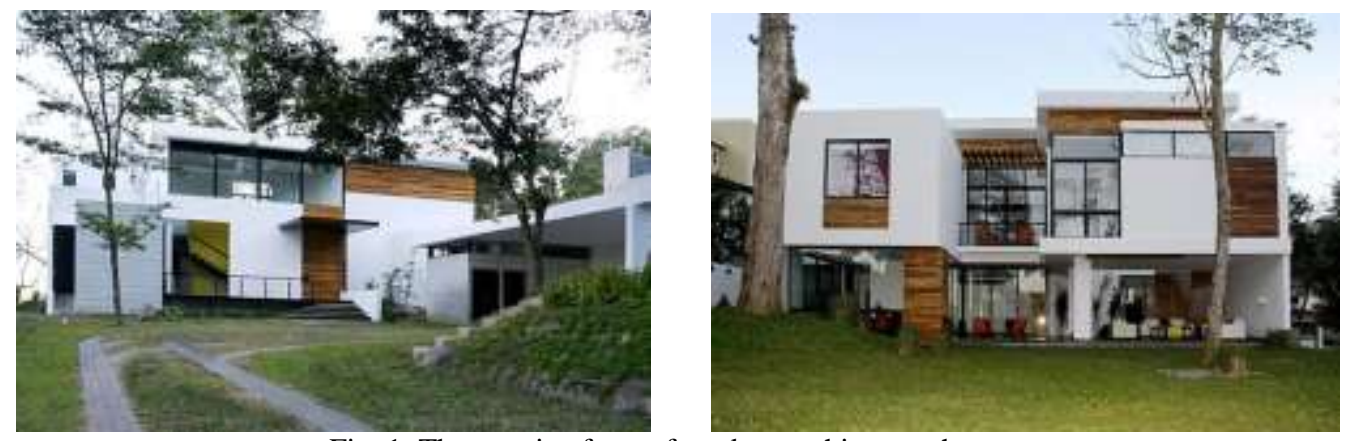

Fig. 1. The genuine form of modern architecture houses Source: (internet, 2011)

\subsection{Television and Rural Society's Daily Lives}

Television culture is a product made by media institution that in facts is part of the social community itself. According to McQuail (2000) ${ }^{3}$, television (mass media), culture and the community (society) are the three things that can't be separated. Television is a cultural product that manifests a society's ideas about a reality (the object). The object is not necessarily displayed as is, but suffered an imaginary reality which is a result from the construction of those who produce the text.

Popular language for this second reality is the representation. According to Hall (2002) ${ }^{4}$, representation is an activity that uses the language of communication that have specific meanings as defined in socio-cultural context to describe, represent, or re-present an object (or reality). So the process of representation is essentially the process of re-construct reality through language that has consensual meaning.

Moreover television is a cultural product, so the existence of the television will never escape from the institution that produced $i^{5}$. In this institution, program maker comprised of several individuals who have the power to re-construct the reality that appear in television, such as chief editor, editor, camera person or even the producer. These individuals are certainly part of the society that has a set of values which is believed as long hereditary in the form of culture. Representation they create in the television, more or less would represent their ideology concerning the ideal of a society.

This ideal form of representation of reality in the end became a discursive practice that is run by the public system to perpetuate the status quo. It could be argued that through the television, institutions that produce them also penetrate the ideology of its readers in the form of representation of reality. So it can be said that the discursive practices that took place in a television, was also taking place in the social reality of society itself. Discursive practices that ultimately produce, reproduce, or even perpetuate the discourse that supports a dominant power that produces "common sense" or "taken for granted" for the public who consume it.

It can be said that the television featuring a symbolic reality which is the factual representation of the reality that occurs in the social environment. Symbolic reality is produced through symbolic interactions formed by the language and conventions (consensual meaning) ${ }^{6}$. So the use of the language used to represent reality is biased and not value-free. Because in every selection of language to be used there are always contain some values inherent in the use of language. The use of language here is not just limited to words, but also on attributes,

\footnotetext{
${ }^{3}$ McQuail, Dennis (2000) "Theory of Media and Theory of Society" in Mass Communication Theories, London: Sage Publication. P. 61.

${ }^{4}$ Hall, Stuart (2002) "The Work of Representation" in Hall, Stuart (editor). Representation; Cultural Representations and Signifying Practices. London:

Sage Publication. P. 15 .

${ }^{5}$ Strinati, Dominic (2007) Popular Culture: Pengantar Menuju Teori Budaya Populer. Bandung: Penerbit Jejak. pp. 5.

${ }^{6}$ Fiske, John (1996) "Communication, Meaning and Sign" in Introduction to Communication Studies. London: Routledge. pp. 53-56.
} 
gestures, as well as languages such television angles, plot or genre ${ }^{7}$. So, basically symbolic realities that exist in the television offer specific values to the audience about the state of an ideal society.

The effects of symbolic reality created by television becoming inevitable for rural society's daily lives. Not only the symbolic reality but television itself also influences the habitual pattern of their lives. In Turen, women usually go to the mosque when Maghrib time arrived but after television present in their lives, they choose to pray in their own houses so they won't miss their favorite show. One of the most favorites television show liked by women in Ngadiluwih and Turen Village is Sinetron (television serial with a very long episodes/soap opera). The program favorite by more than $80 \%$ women's in both areas. Moreover, they considered that everything shown in the television, or particularly in sinetron, is the symbol of modernity in urban life. This includes the architecture role model they used to build their houses to presenting their status.

\subsection{Houses and Spaces Used in the Village}

\section{From the research I conduct, this is the result on photographic of rural society's houses:}
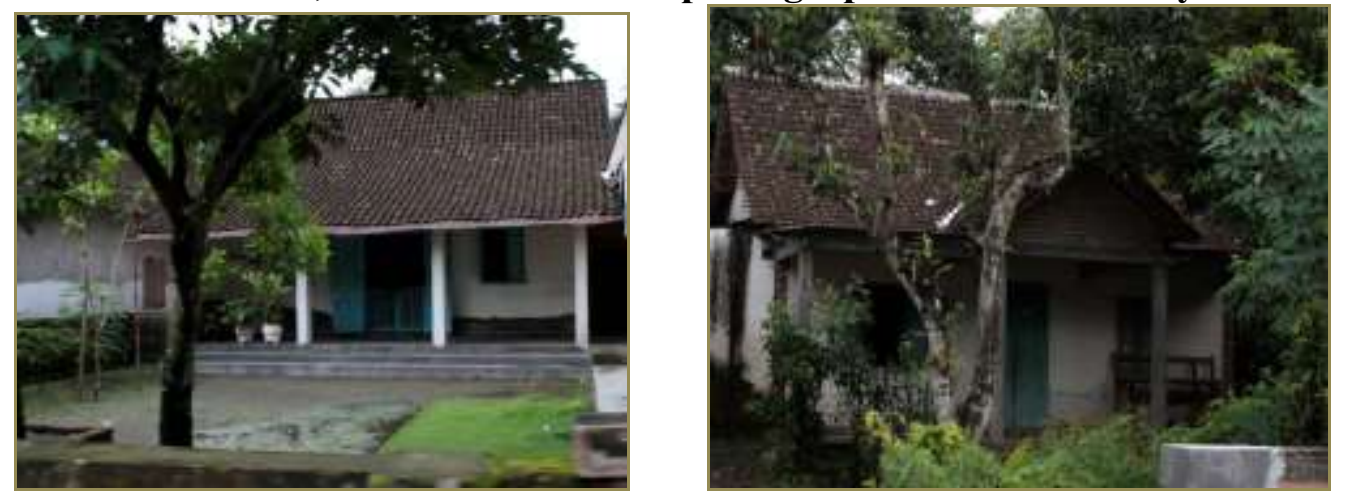

Fig. 3. The traditional houses in Ngadi Luwih Village

Source: (Research documentation, 2011)

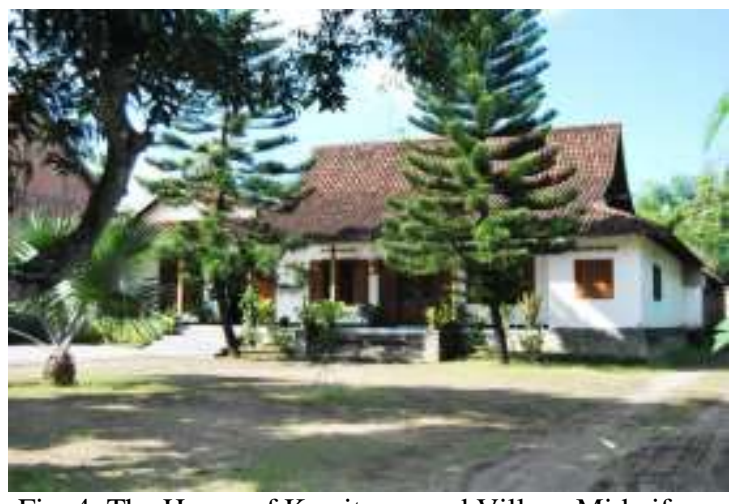

Fig. 4. The House of Kamituwo and Village Midwife Source: (Research documentation, 2011)

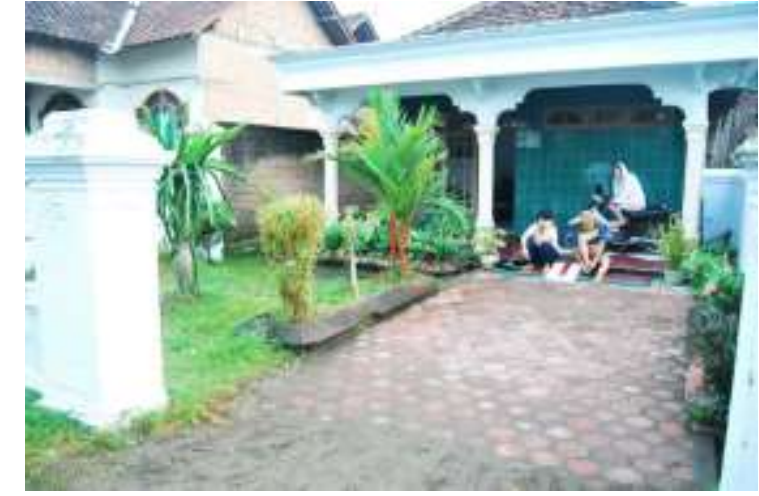

Fig. 5. The Workhouse of Kamituwo in Ngadiluwih Source: (Research documentation, 2011)

\footnotetext{
${ }^{7}$ McLaughlin, Linda (2000) The Language of Magazines. New York: Routledge. pp. 8.
} 


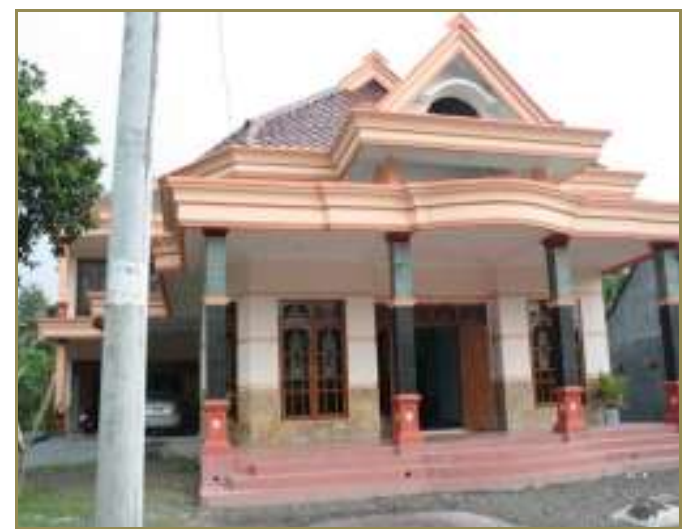

Fig. 6. The House of Villager in Ngadiluwih that considered as Modern Source: (Research documentation, 2011)
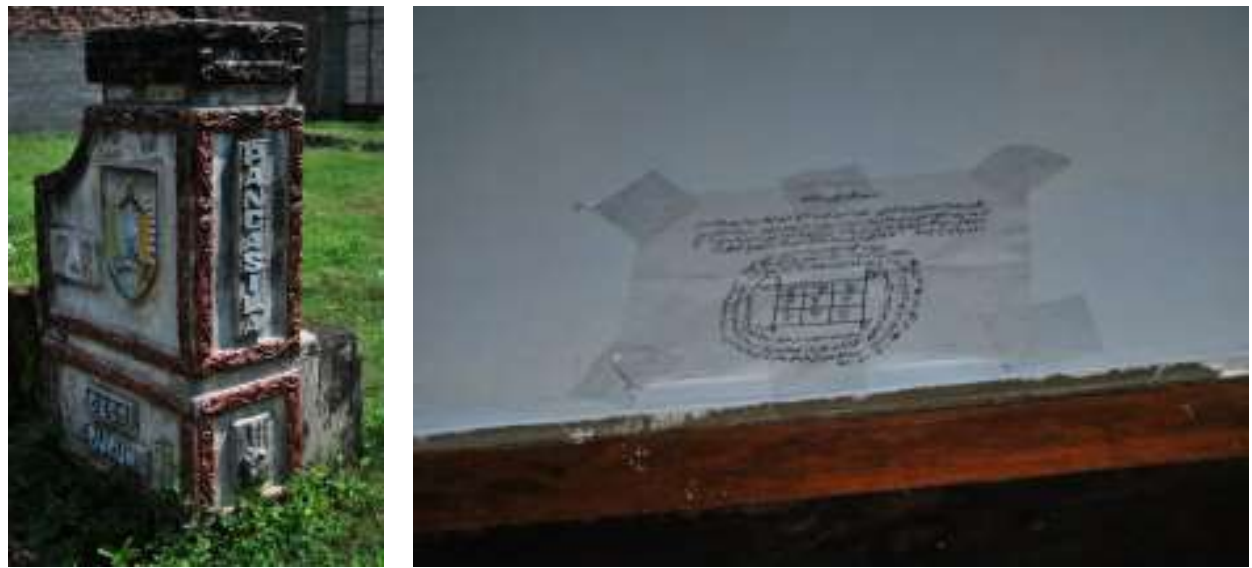

Fig. 7. Local Values Presented in the form of artifact in the building Source: (Research documentation, 2011)

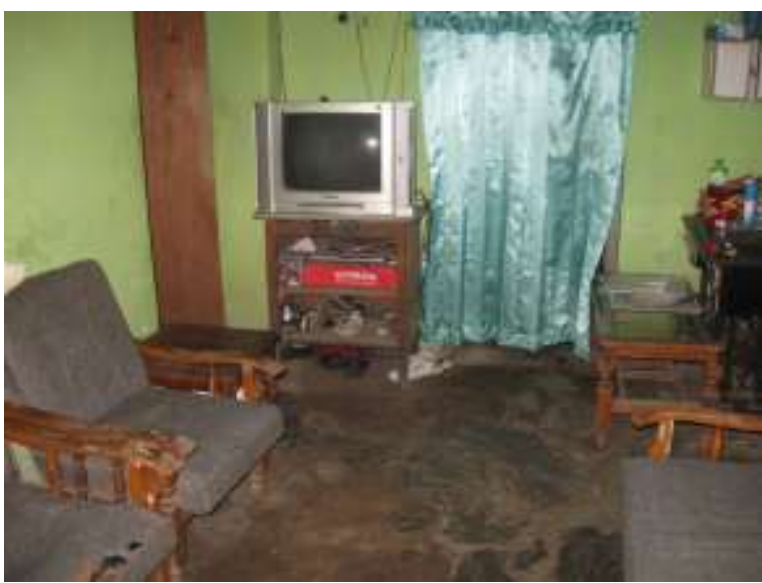

Fig. 8. The separation of Public and Private area of the house Source: (Research documentation, 2011)

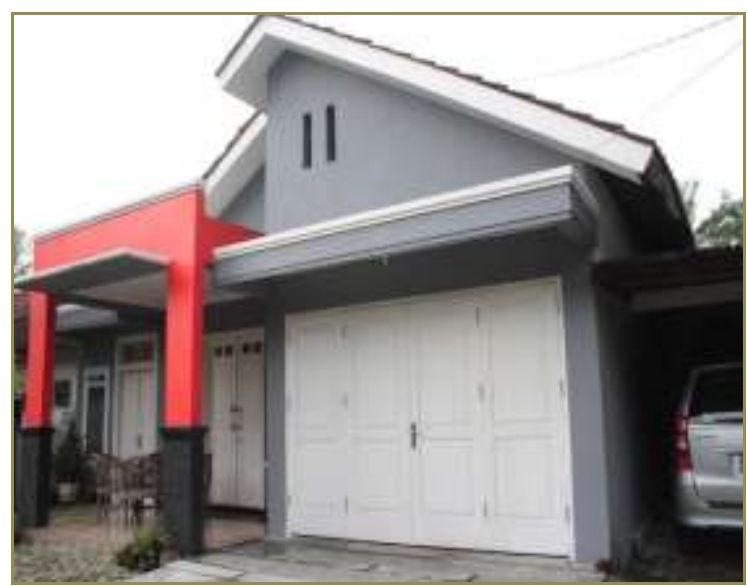

Fig. 9. The only house that follow basic rules of modern house Source: (Research documentation, 2011)

\subsection{Rural Society's Interpretation of Modern Architecture}

In Figure 3, we can see the common architecture used by the rural society to build their houses. Like any other agricultural based area, the space usage characterized by relatively wide space surrounding the main building with agricultural function. This is match with Otto ${ }^{8}$ description about rural houses:

\footnotetext{
${ }^{8}$ Groover, Mark D. (2003). An Archeological Study Of Rural Capitalism And Material Life: The Gibbs Farmstead in Southern Appalachia, 1790-1920. New York: Kluwer Academic Publishers. pp: 9-29
} 
a diffuse settlement pattern of scattered farmsteads and rural neighborhoods, which allowed fewer persons to claim more territory; commonly practiced techniques of horizontal log construction, which permitted rapid assembly of houses, churches, and courthouses; an easily replicated economic, religious, and political infrastructure of crossroad hamlets, independent churches, and courthouses; and a generalized stockman-farmer-hunter economy with a productive and adaptable food-and-feed complex and an extreme adaptability with regard to their commercial crop (Otto 1985:186)

In the rural area the material used to build their house come from nature like wood or bamboo but after modernity came they used bricks as the symbol of modern status. That's why, you will meet several houses that combining bamboo and brick wall in their basic structure.

There's a common discourse about modern architecture and livable space in rural society's perception. Shown in figure 5 and 6 is the manifestation of modern architecture in their perception. This modern livable space characterized by large brick based building, the unified toilet and bathroom inside the house, tile usage in all around the house and in the front wall, much pillar used for the signature symbol of modernity and full contrast-colored paint and decoration. They admit that this is their adopt manifestation from the houses shown in sinetron, just like Kartinah said:

Yes Miss, this is the appearance of the house. I don't really understand about housing and architectural knowledge. This house actually duplicated from houses that shown in sinetron. In this village, house with similar architecture will be found when one of the person works in foreign country or rich people and they all adopt it from sinetron. So we can be a little bit modern.

(Interview with villagers, Source: research documentation, 2011)

In figure 4 and 5 basically shown how Kamituwo, (village elder and very respectable person) defined his usage of livable space. Kamituwo has two houses in the village. One is the workhouse and the other is the house he live in with his wife that accidently also midwife of the village. Kamituwo separated his public and private space through the houses. In workhouse he basically created what so called modern architecture as the basic foundation of the building. The purpose of this building is to meet people from another village or government, that's why he thinks it will be more appropriate and showing his status. In contrary, he used his old village house as space in his daily lives and his wife working space. The reason why lies in his mind about private and public places, shown in his words:

I prefer to live my old house that I've been lived for years. However, would be impossible for me to accept guesses in this hose that considered traditional. In this house, even the bathroom and toilet separated from the main house. So, I made my modern workhouse. However, my wife is the village's midwife. So, I rather feel uncomfortable if she uses my workhouse. Basically, it would be better if my wife works in this house, that's it.

(Interview with Kamituwo, Source: research documentation, 2011)

Figure 8 shows another space usage in term of separating public and private life. In Turen village which closer to the urban area, people used curtain to separate their private area from public. In the village that communalism tends to be dominant discourse it would be taboo to put solid material as the separation symbol of their spaces. That's why they used the curtain.

Figure 7 showing the modification of their manifestation of modern architecture. In front of the house they still put gate symbol signified the sense of welcoming. In that gate, we can see how the rural society speaks their ideology bluntly. Still shown at the gate, Pancasila's symbols and other main discourses that present in the new order regime such as KB. This modification is a certain condition for the rural society's to build their modern houses. Moreover they still considered the articulation of their ideology as important as showing their nationality even though it consider as traditional. Furthermore, articulation of their local value also shown in some part of the house with the appearances of mystical amulet surrounding the houses to repel evil energy.

Instead of always founding modification houses that combine the modern and traditional value my research found the genuine modern house following the basic philosophical of modernity shown in figure 9. This house belong to Mr. Sudono who works as government civil engineer. He realized that the appearance of his house doesn't match with any other houses in the village but so far, none of the villagers discriminate him for it. 
Anyhow, Mr. Sudono admit that some of his neighborhood asked why there's no welcoming gate in front of the house and another question about leaving the traditional values of the village. Like Hyungmin's ${ }^{9}$ statement:

On the other hand, the pattern book, like most advice books, was composed mostly of text accompanied by plans and perspective views of rural detached houses. Architectural historians, approaching these texts as a reflection of changing styles and tastes, have viewed this transition from the builder's guide to the pattern book as a phenomenon that paralleled the decline of the Greek revival and the rise of the picturesque.

\section{Conclusion}

In conclusion, villagers considered as part of rural society thinks that everything represented in the television is the genuine form of modernity. That assumption brings consequences into their perception about house architecture considered as modern. So they adopt the classical architecture shown in the houses of sinetron into their houses with certain modification. The basic assumption for this modification departs from their local value and wisdom. Not only modification in the form of the building itself but also in the functions and the material used.

However, I strongly agree that people in my research tend to hold on their traditional value as villagers. Even though they adopt architecture they considered as modern, they still honoring traditional values by put them in the houses. People in rural society also tends to separate the space that have public function of the building by making it more modern than the other parts of house but hold still the traditional form of local value in the private space. They knew that modern wave is something inevitable and the modernization agent come into their houses in the form of television content. That's why they make a "compromised" house which combined the modern value represented in television and their local value. However, what they considered as modern architecture was not the exact form seen from the philosophical and theoretical perspective.

Thus, what rural society interprets as modern architecture from the representation in television was not the genuine form of modern architecture, theoretically and philosophically.

\section{References}

[1] Cacciari, Massimo, Architecture and Nihilism: On The Philosophy Of Modern Architecture, London: Yale University Press, 1993, pp. 143-195.

[2] Downton, Paul F, Ecopolis: Architecture And Cities For A Changing Climate, Australia: Springer Science Publishing, 2009, pp. 179-220.

https://doi.org/10.1007/978-1-4020-8496-6_6

[3] Fiske, John, "Communication, Meaning and Sign" in Introduction to Communication Studies. London: Routledge, pp. 53-56.

[4] Groover, Mark D, An Archeological Study Of Rural Capitalism And Material Life: The Gibbs Farmstead in Southern Appalachia, 1790-1920, New York: Kluwer Academic Publishers, 2003, pp: 9-29.

[5] Hall, Stuart, "The Work of Representation" in Representation; Cultural Representations and Signifying Practices. London: Sage Publication, pp. 1-87.

[6] McLaughlin, Linda, The Language of Magazines. New York: Routledge. pp. 8-23.

[7] McQuail, Dennis. "Theory of Media and Theory of Society," in Mass Communication Theories, London: Sage Publication, 2000, pp. 47-85.

[8] Pai, Hyungmin, The Portfolio and The Diagram: Architecture, Discourse and Modernity in America, Cambridge: The MIT Press, 2002, pp. 12-83.

[9] Strinati, Dominic, Popular Culture: Pengantar Menuju Teori Budaya Populer, transl. Bandung: Penerbit Jejak, pp. 156.

\footnotetext{
${ }^{9}$ Pai, Hyungmin. (2002). The Portfolio and The Diagram: Architecture, Discourse and Modernity in America. Cambridge: The MIT Press. pp. 12-83
} 